\title{
Common standards, different stakes: A comparative and multi-scalar analysis of accountability reforms in the Spanish education context
}

European Educational Research Journal

(C) The Author(s) 2018 Reprints and permissions: sagepub.co.uk/journalsPermissions.nav DOI: I0.1 I77/|474904 I I8785556 journals.sagepub.com/home/eer

@SAGE

\author{
Antoni Verger \\ Universitat Autònoma de Barcelona, Spain
}

\section{Miriam Prieto}

Universidad Autonoma de MadridSpain

\section{Marcel Pagès}

Universitat Autònoma de Barcelona, Spain

\section{Patricia Villamor}

Universidad Complutense de Madrid, Spain

\begin{abstract}
An increasing number of countries are adopting accountability systems in education that rely on the external evaluation of students' learning outcomes through standardized assessments. The international dissemination of this form of accountability, often known as test-based accountability, does not imply that exactly the same policy is adopted everywhere. Accountability reforms, as any other globalizing policy model, are context-specific. The concrete form that accountability reforms adopt is contingent on a range of political, historical and institutional conditions, and to policy-making dynamics and logics that operate at multiple scales. This paper analyzes the trajectory of accountability reforms in two Spanish regions, Madrid and Catalonia, from a comparative and multi-scalar perspective. Based on document analysis of media and official sources, and exploratory interviews with key informants, the paper shows that, although these two regions have pioneered the adoption of test-based accountability reforms in the Spanish context, their accountability systems have evolved quite differently. While accountability reforms in Madrid have been oriented toward the promotion of school choice and competition, Catalonia has adopted an uneven lower-stakes accountability approach with multiple ramifications. In this paper, we explain how and why such diverging trends have been possible within the context of a common general regulatory framework.
\end{abstract}




\section{Keywords}

Accountability, education reform, global education policy, multi-scalar analysis, Spain, standardized testing

\section{Introduction}

Accountability has gone global in the education policy arena. Currently, most education systems in the world are adopting more sophisticated evaluation technologies of students' learning that are increasingly used to hold schools accountable (Lingard et al., 2013). As part of this global trend, school-level educational actors, including teachers and principals, are required to be more open and responsive to external judgment about their work and results. As the concept of accountability implies, if educational actors do not follow the expected behaviors and/or do not meet the expected results, they may face consequences (Bovens, 2007). The form of accountability that is spreading more intensively in education has an outcomes-based nature. This is an accountability approach that focuses on students' learning outcomes and that involves the generation of data through largescale standardized evaluation instruments - the reason why this model of accountability is also known as performative accountability (Ranson, 2003), results-driven accountability (Anderson, 2005), or test-based accountability (Hamilton et al., 2002). Some of the most common consequences of test-based accountability include the association of test results to teachers' promotion, the encouragement of school choice via the release of league tables, or the stricter supervision of underperforming schools.

The fact that test-based accountability is globalizing does not mean that accountability systems are adopting the same form everywhere, or that they are enacted for exactly the same reasons, or to address the same types of educational problems. Accountability systems can differ significantly according to who is expected to provide the account, to whom is the account owed, what is to be accounted for, and what are the consequences of providing an account (Leithwood and Earl, 2000). Overall, as happens to any other global policy model, the trajectory of accountability reforms is context-specific, and the final form that accountability systems adopt is contingent on a broad range of political, historical and institutional conditions.

The main objective of this paper is to analyze the emergence and trajectory of accountability policies in the Spanish educational context during the period between 2003 and 2016, with a focus on two different regions: Madrid; and Catalonia. Since the Spanish education system is highly decentralized, our study focuses on the regional level. Out of the 17 Spanish regions, Madrid and Catalonia have been selected because these two regions have pioneered the adoption of accountability reforms in the Spanish educational context, but also due to the interest of analyzing these two cases from a comparative perspective. Despite Madrid and Catalonia sharing a general education regulatory framework in education, their accountability systems have evolved quite differently, with Madrid adopting a market accountability system that is incrementally oriented toward the promotion of school choice and competition, and Catalonia rather adopting a low-stakes accountability approach, but with multiple ramifications. Thus, the two selected cases represent a relevant example of policy divergence in a context of multi-scalar education governance.

The paper opens with the analytical framework we have applied to this study on educational reforms in a multi-scalar scenario. It follows with a brief description of the Spanish educational context, which is characterized by a historical public-private partnership (PPP) in educational provision, and a progressive adoption of new public management (NPM) measures. As we develop in the following sections, both Catalonia and Madrid have developed different accountability systems within this common institutional and regulatory framework. The section on Catalonia is 
divided into two main stages, which correspond to two different political periods of educational change - one with a progressive coalition governing the country, and the other one with a conservative government. In Madrid, two main stages are identified as well, but they correspond to an incremental accountability reform process that has been led by the same conservative government. In both Catalonia and Madrid, we have identified dynamics of social and political resistance to the accountability reforms, to which we also refer to when developing the two cases. The paper concludes with a comparison and discussion of the main results.

\section{A multi-scalar approach to global education policy}

Education policies and agendas are increasingly structured globally and framed by globalizing ideologies and policy paradigms such as NPM. However, the emergence of global education policies does not mean that domestic education systems are converging globally. The effects of globalization in education policy are mediated by institutional legacies, translation dynamics, and the complex interplay between global forces and domestic politics, among other contingencies (Maroy et al., 2016). Research on the re-contextualization of global education policy traces the different interpretations and translations of global policy programs and tries to find out about the multiple relationships that reconstitute such programs in different scales (Mukhopadhyay and Sriprakash, 2011). This type of research stresses that borrowed policy ideas are modified, vernacularized or even resisted as they are enacted in different places (Steiner-Khamsi and Stolpe, 2006). Consequently, global policy models tend to develop into multiform policy patterns (Ball, 2016; Schriewer, 2012).

Broadly speaking, global education policy research pays attention to the mediating role that factors and contingencies of a different nature play in the adoption and re-contextualization of global reform models. These include factors of a political nature such as: the influence of partisan politics, pressure groups and/or veto players in policy-making processes; economic factors, or how the level of economic development of countries and regions conditions what are the main problems that education policy should address, but also what policy solutions are administratively and financially viable; institutional factors, usually understood as the mediating role of public administration traditions and regulatory frameworks in the adoption and transformation of certain policy reforms; and cultural factors, which often relate to the semiotic and meaning-making dimension of education policy processes, but also to how social values or public opinion are more or less conducive to the selection and retention of certain policy solutions (Verger et al., 2016).

In the case of highly decentralized education systems, as the one we analyze in this paper, multiscalar interactions intensify and add complexity to policy analysis, since additional scales of governance - which are mutually-embedded by definition - intervene in the adoption and enactment of educational reform processes (Robertson, 2012). Adopting a multi-scalar governance approach is not only a matter of understanding policy spaces as hierarchically organized. It implies looking at the political, economic and cultural dimensions of inter-scalar interactions, as well as to how scalar policy-making practices are produced by different political logics and social groups (Papanastasiou, 2017). Overall, a multi-scalar conception of policy processes invites us to unpack the nature of global educational reform by exploring who controls what in which scale, from the regional to the supra-national, and the inter-relationships therein (Dale, 2005).

Federal or decentralized policy regimes are usually seen as convenient settings where to undertake comparative education analyzes, since these regimes allow for the control of a broad range of mediating variables, including variables of a regulatory or socio-economic nature (Carnoy, 2015). Nonetheless, as just mentioned, these regimes also introduce complexity to political analysis in the sense that the level of scalar interaction and the overlapping of meaning-making practices intensify and permeate the politics and economics of educational reform. Furthermore, in cases in which national identities are strong at the regional level - such as is the case we explore here - these 
identities are behind a range of additional dynamics of competition, contestation and construction of policy boundaries among multiple scales (Gallego et al., 2017).

Methodologically speaking, and as a way to track the role of all these different variables within the policy trajectory of accountability reforms in two Spanish regions, we base our analysis on Kingdon's theoretical model of policy change. According to Kingdon (1984), educational reforms, as any other type of institutional transformation, happen or, at least, are more feasible when different 'streams', namely, the political, the problem and the policy streams - all of which have their own internal logic and might evolve autonomously - are coupled. In his model, the problem stream refers to the moment in which a policy or social problem gains attention; the policy stream refers to whether a solution to the problem in question is available and feasible; and the political stream refers to the political motives and opportunities for those in office to enact the solution in question (Kingdon, 1984).

The policy narratives deployed by policy-makers and other relevant stakeholders are an important entry point to explore how the mentioned streams evolve in specific educational settings and might converge in particular junctures (see Gray and Jones, 2016). Policy narratives, as well as other forms of meaning-making, can be captured in official documents, in the media or by conducting interviews with policy elites. For the specific purpose of elaborating this paper, we have resorted to document analysis of policy briefings, press releases, media kits and legal documents, published by different education stakeholders (regional educational administrations, principals, teachers' unions, parents' associations or think tanks), and to exploratory interviews with key informants in both Madrid and Catalonia.

\section{The Spanish education context}

Since the approval of the 1978 Constitution, the Spanish administrative structure was drastically reformed via the decentralization of the state in seventeen 'Autonomous Communities'. The emerging regional governments were provided with important levels of administrative autonomy in key areas such as education, health and welfare. Catalonia, the Basque Country and Galicia achieved higher levels of competences due to historic, cultural and political reasons, and they got these competences earlier than other regions. For instance, Catalonia got competences in education in the beginning of the 1980s, whereas Madrid only got them in the year 2000. The high level of administrative decentralization that prevails in Spain is far from harmonious. In fact, in Spanish education, political conflicts for competencies, and tensions around linguistic policies and curriculum control are recurrent among the different scales of governance (Engel, 2008).

The Spanish education system is organized as a PPP in which the private sector plays an important role in educational provision. In the 1980s, the Catholic Church influenced decisively a reform process that ended up with the consolidation of a dual public education system in which private schools (mainly religious) could receive public funds on the condition that they follow public sector regulations. This PPP framework, in its time, allowed for an important education expansion at a low cost. However, there are also important drawbacks in its implementation, including issues of students' discrimination in enrolment processes and the collection of uncovered fees to families in PPP schools (Benito and González, 2007). The presence of PPP schools is particularly high in regions such as Madrid, Catalonia and the Basque Country.

The PPP framework has contributed to the growing politicization and dualization of education debates in Spain. Both progressive and conservative governments have generated an overproduction of norms and regulations in order to respond to different and often contradicting social demands on education (Bonal, 2000). In total, seven education reforms have taken place in Spain since the restoration of democracy in the end of the 1970s. Previous education reforms in Spain (from the 1970s to the 1990s) have had a more systemic character and have focused on inputs, 
processes and pedagogy. In contrast, the most recent reforms have a clearer focus on school governance, leadership and management. This last generation of education reforms follows an NPM rationale that challenges the horizontal style of school governance that has prevailed in Spain since the transition to democracy. The most recent educational reform, promoted through the Quality in Education Improvement Law (LOMCE for its acronym in Spanish) is a paradigmatic case of NPM in education since the main components of the law are the promotion of school autonomy, the professionalization of principals and the introduction of external standardized tests (Parcerisa, 2016). This reform was framed and justified by resorting to evidence coming from the Programme for International Student Assessment (PISA) and to other Organization for Economic Co-operation and Development recommendations focusing on the potential benefits of school autonomy with accountability in the governance of education (Choi and Jerrim, 2016; Parcerisa, 2016).

However, as we show in the following sections, the regional governments have a great capacity to shape some of the elements included in the Spanish legislation by enacting them selectively, and to generate their own regulations on school governance and accountability.

\section{The uneven trajectory of accountability policies in Catalonia}

At the turn of the millennium, the public debate on education was intense in Catalonia, with the National Conference of Education being celebrated between the years 2000 and 2002, and a National Agreement on Education being debated between the years 2004 and 2006. In the context of these two initiatives, significant changes in the governance of education were advocated, and policy principles such as school autonomy, co-responsibility and accountability gained centrality in the Catalan education debate. In fact, both initiatives triggered a long and disputed education reform process that would crystalize in the 2009 Catalan Education Reform Act (Farré, 2009).

Table I. Political periods and contemporary educational reform in Catalonia.

\begin{tabular}{|c|c|c|c|c|c|}
\hline Period & President & $\begin{array}{l}\text { Political } \\
\text { orientation }\end{array}$ & $\begin{array}{l}\text { Education } \\
\text { department }\end{array}$ & $\begin{array}{l}\text { General education } \\
\text { policies and reforms }\end{array}$ & Accountability policies \\
\hline $2003-2006$ & $\begin{array}{l}\text { Pasqual } \\
\text { Maragall }\end{array}$ & Progressive & $\begin{array}{l}\text { Josep } \\
\text { Bargalló/ } \\
\text { Marta Cid }\end{array}$ & $\begin{array}{l}\text { National Agreement } \\
\text { on Education } \\
\text { School Autonomy } \\
\text { Projects }\end{array}$ & $\begin{array}{l}\text { Continuity (sample-basec } \\
\text { evaluation) and specific } \\
\text { program's evaluation }\end{array}$ \\
\hline $2006-2010$ & $\begin{array}{l}\text { José } \\
\text { Montilla }\end{array}$ & Progressive & $\begin{array}{l}\text { Ernest } \\
\text { Maragall }\end{array}$ & $\begin{array}{l}\text { LEC (Catalan Education } \\
\text { Reform Act) }\end{array}$ & $\begin{array}{l}\text { 2009: Final Period } \\
\text { Evaluation (in primary } \\
\text { education) } \\
\text { 2009: Diagnostic } \\
\text { Evaluation } \\
\text { 2010: Evaluation Decree }\end{array}$ \\
\hline $2010-2012$ & $\begin{array}{l}\text { Artur } \\
\text { Mas }\end{array}$ & Conservative & Irene Rigau & $\begin{array}{l}\text { Budget cuts in the } \\
\text { education sector } \\
\text { Teaching Personnel } \\
\text { Decree }\end{array}$ & $\begin{array}{l}\text { 2010: Cancellation of the } \\
\text { Evaluation Decree } \\
\text { 2012: Final Period } \\
\text { Evaluation (in secondary } \\
\text { education) }\end{array}$ \\
\hline $2012-2016$ & $\begin{array}{l}\text { Artur } \\
\text { Mas }\end{array}$ & Conservative & Irene Rigau & $\begin{array}{l}\text { Budget cuts in } \\
\text { education } \\
\text { Basic Skills Program }\end{array}$ & $\begin{array}{l}\text { 2013: Pedagogic Audits } \\
\text { 20I4: AVAC (Catalan } \\
\text { Annual Schools' } \\
\text { Evaluation) }\end{array}$ \\
\hline
\end{tabular}




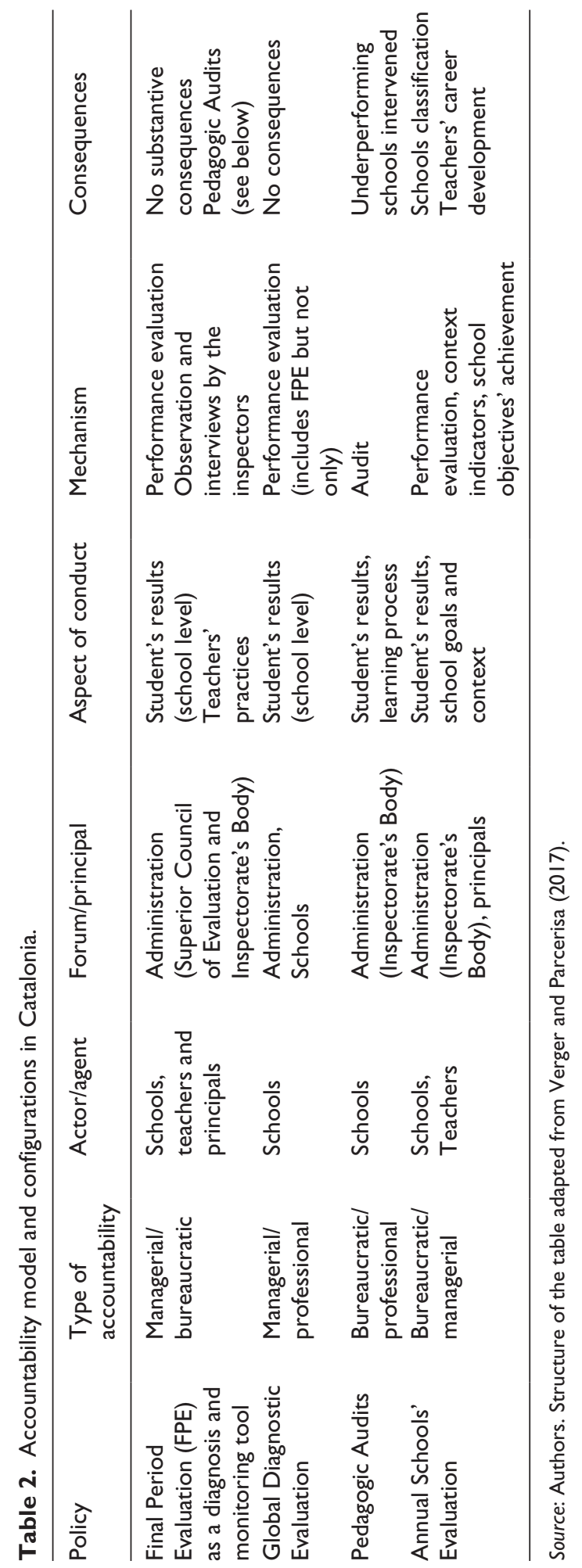




\section{The progressive government (2003-2010): pioneering NPM and modernizing education}

After 23 years of conservative governments in Catalonia since the restoration of democracy, a governmental change took place in 2003 with a broad progressive coalition (including social democrats, greens and left-nationalists) taking over. The first educational measures of this government were aligned with the main priorities stated in the National Agreement on Education and, especially, with the school autonomy proposal. In fact, the main governmental policy program at that time in terms of scope and resources consisted of the promulgation of a School Autonomy Program that aimed at advancing the pedagogic and organizational autonomy of schools. Schools taking part in this program were expected to design a context-sensitive 'school autonomy plan' to address and mitigate school failure and promote social cohesion and equity in education. If approved, schools would receive a significant grant to be used to achieve the objectives defined in their plan. In exchange, schools would need to be externally evaluated and implement self-evaluation mechanisms, as well as to receive training on strategic planning and school leadership from the Education Department (Garcia-Alegre and Del Campo-Canals, 2012). Despite its origins as a pilot-program, half of the Catalan primary and secondary schools ended up having School Autonomy Plans (Bonal and Verger, 2013).

In this same period, a central political event took place in Catalonia: the approval of the new Catalan Autonomic Statute (2006). This new Statute would have significant implications in the future development of educational reform because, among other new competences, it did allow the Catalan government to generate its own sectoral laws in core policy domains such as education. The second progressive government, which started in 2006, would take political advantage of this emerging regulatory opportunity to lead the development of the first Catalan Education Reform Act (LEC, for its acronym in Catalan) (Verger and Curran, 2016: 116).

The education minister with the second progressive government (2006-2010), the social-democrat Ernest Maragall, put an important emphasis on a managerial perspective to educational reform and, to a great extent, embraced the main principles of NPM. In his public and private interventions, the education minister insisted on the need to make state apparatuses slimmer and more oriented toward results and complained about previous governments' acceptance of the 'mediocrity' that prevails in public schools, being especially critical about the presence of uncommitted teachers in the system (Verger and Curran, 2016). In accordance with the NPM tenets, the minister considered that, in education, 'the administration has to do four things: correct planning, regulation at the minimum, adequate provision and evaluation. That's enough' (Maragall, 2009: 10). However, in his view, the bureaucratic culture of the education system was 'resistant to change, as happens to all consolidated and strong systems' (Maragall, 2009: 3).

The strong emphasis on NPM principles and discourses impregnated the education reform process and, in particular, the deliberations behind the enactment of the LEC. In fact, the NPM focus, together with the lack of a clearer support to public education, changed the expected balance of supports and rejections to the LEC in the Parliament. The green party, which was part of the governmental coalition, ended up voting against the law, and the Catalan conservative party, which was in the opposition, voted in favor. The law faced also the strong opposition of the teachers' unions, which organized three sectorial strikes against the law previously to its approval.

In 2009, in the same year of the LEC approval, two different evaluations of the school census started being implemented in Catalonia, namely the Final Period Evaluation (FPE) and the Global Diagnostic Evaluation (GDE). ${ }^{1}$ The former is an external standardized evaluation carried out by the Superior Council of Evaluation, a governmental agency focusing on evaluation in education created in 1993, to 6th grade primary education students. The main goal of the FPE is to measure 
the basic skills of students in order to improve and orient teaching and policy (Resolució EDU/1037/2009²), although it has become, de facto, an instrument to measure schools' performance. On its part, the GDE is conceived as a self-evaluation process that schools have to apply yearly to 5 th grade primary education students and to 3 rd grade secondary education students ${ }^{3}$ as a way to promote school improvement. Despite its internal and self-evaluation nature, both the test and the guidelines of the GDE are designed by the Superior Council of Evaluation, and school inspectors develop a supportive role within its implementation process.

The two large-scale evaluation initiatives described are supposed to work as a formative evaluation to improve school performance and the development of school autonomy, but without generalized consequences for those taking the test (i.e., the students) and their teachers. In fact, these evaluations were justified under the frame of the Spanish Education Law (LOE), in force between the years 2006 and 2013, as it defines 'the need to establish evaluation mechanisms capable to combine the education system goals and the needed pedagogic and management autonomy of schools' (Resolution EDU/1037/2009). The schools' identity cannot be identified in the public reports produced on the basis of these evaluations. ${ }^{4}$

In 2010, the core principles of the LEC were developed through three main decrees: the 'School Autonomy Decree'; the 'School Principals Decree'; and the 'Evaluation Decree'. The 'School Autonomy Decree' defined school autonomy as a multidimensional concept that covers aspects of both pedagogy and the management of schools - although it was more concrete in how to develop managerial than pedagogic tasks at the school level. The 'Principals' Decree' defined the new roles of school leaders through the professionalization of its functions and an increasing range of attributions in new areas of decision-making such as teachers' selection and evaluation. Finally, the 'Evaluation Decree' defined the creation of an independent evaluation agency that would be able to evaluate a broad range of dimensions of the educational system, many of which had not been systematically evaluated until then, including teachers' performance (Bonal and Verger, 2013; Collet-Sabé, 2017).

\section{The conservatives are back (2010-ongoing): 'back to basics' for education success}

In November 2010, the Catalan conservative party won the elections and a new government was constituted. One of the first decisions of the new government was to cancel the creation of the independent Education Evaluation Agency. The government argued that, in the context of the financial crisis, it was not feasible to create a new public agency, although it is also known that the conservative government was reluctant to create an independent evaluation body out of the Education Department's direct control (Verger and Curran, 2016).

The first phase of this new conservative period was characterized by the application of important budget cuts in all types of public services. In education, these cuts meant, among other things, an increase of the teachers' working load, a reduction of teachers' salaries, and the elimination of some emblematic educational programs, including the School Autonomy Plans. The budget cuts limited but did not impede the Catalan government advancing its own education policy agenda. With the conservative government, the LEC was developed in a very selective way (Bonal and Verger, 2013). Specifically, the conservative Education Minister, Irene Rigau (December 2010-January 2016), focused on three particular areas of educational reform. First, the government focused on strengthening the figure of schools' principals by giving them more power in the selection of the teaching staff (Decree 39/2014) 5 and by establishing qualification procedures for those teachers aiming to become school principals.

Secondly, the government promoted common core curricular standards in core knowledge areas such as Mathematics and Language via a so-called 'basic skills' program. This program, together with the elimination of the School Autonomy Program and the intensification of external 
evaluation instruments (as we describe below), somehow contributed to narrow the curriculum and to reduce the pedagogic autonomy of teachers and schools (Verger and Curran, 2016).

Thirdly, with the suspension of an independent evaluation agency, the Inspection Services and the Superior Council of Evaluation saw their education evaluation competences amplified. For instance, the Superior Council of Evaluation's FPE was expanded in 2011 to the secondary education level (ENS/2780/2011). ${ }^{6}$ At the same time, the government reformed the FPE test to align it with PISA contents, approach and standards. As the government admitted in its 2012 National Plan for School Success,

The levels fixed for each objective [in the plan] are established from the correspondences between the levels of the FPE test (2012) in primary and secondary education, and the levels of the new tests which since 2013 will be adapted to the methodology and PISA exigencies as well as to the new curricular model. ${ }^{7}$

This apparently technical change in the national assessment system was seen as a mechanism for the Catalan Government to improve the performance of Catalan schools in PISA. In fact, when the PISA 2015 report was released, the Education Department attributed the results' improvement in this international test to the fact that it had aligned its national assessment system to PISA - metrics and procedures. ${ }^{8}$ In the meantime, the Inspection Services have acquired new areas of competence and adopted two new school evaluation programs, namely the Pedagogic Audits and the Annual Schools' Evaluation.

1. The Pedagogic Audits aim at improving underperforming primary schools (i.e., schools with more than $30 \%$ of students underperforming in the FPE test) through an 'integral and exhaustive analysis of each school' with 'specific intervention purposes for key aspects of betterment' (Education Department, Annual Report, 2015: 6). The Pedagogic Audits represent the first accountability mechanism with concrete consequences for schools in the Catalan education system, in the sense that underperforming schools become externally intervened. Since 2014, about one-hundred primary schools have been audited, and the Education Department is considering expanding this initiative to secondary education.

2. The inspectors have developed the so-called Annual Schools' Evaluation (AVAC for its acronym in Catalan), as a way of responding to the governmental request of classifying schools according to their level of effectiveness. ${ }^{9}$ The AVAC defines schools' effectiveness according to students' learning outcomes - in both external evaluations (i.e., FPE) and self-evaluations - and measures the progress of school against social indicators. ${ }^{10}$ The AVAC has been also used to promote teachers being paid according to their level of productivity. Teachers who are in highly effective schools according to AVAC can apply for a voluntary individual evaluation in order to obtain salary bonuses (Order ENS/330/2014). In this evaluation, teachers need to demonstrate their specific contribution to the success of the school, and the school principal validates such an assessment. Nonetheless, not many teachers have applied to this evaluation so far because of the existence of easier alternatives to promotion within the salary scale.

Overall, the widening of school inspectors' competences and instruments reflects the preference of the conservative government for the recentralization of school control and more hierarchical and bureaucratic forms of accountability.

\section{Responses to accountability}

The development of the accountability system in Catalonia is aligned with measures that are included in the controversial Spanish LOMCE education reform act, which promotes standardized assessments in both primary and secondary education. The LOMCE evaluations, despite that they are grounded on similar evaluations to those being implemented by the regional administration, 
have generated a high level of criticism within the educational community in Catalonia for two main reasons. First, because at some point the LOMCE threatened with the evaluations having certification effects for students and, second, because these evaluations were advanced in the context of a very explicit neoliberal discourse on educational reform. An important oppositional campaign to the standardized evaluations coming from teachers, but especially families, has been organized, and since 2014 more than 1500 families have boycotted the tests. ${ }^{11}$ According to the organizers of this campaign, the Education Department has asked the inspection to closely supervise the role of principals in the schools that take part in the boycott and has suggested them to repeat the test in order to prevent disciplinary sanctions. ${ }^{12}$ The Education Department denies these threats and argues that the boycott was based on 'misinterpretations' and a climate of 'political contamination'. ${ }^{13}$

More recently, the Catalan education system has been shaken by a big public debate on pedagogic innovation. This debate has been promoted and articulated by a campaign called 'Escola Nova 21 ' that is backed by a group of philanthropic foundations and policy entrepreneurs and has received the economic and administrative support from both private and public sources. This campaign advocates for Catalan schools adopting innovative pedagogies and transmitting a broader range of skills - including soft-skills - as a way to help students to adapt themselves to the economic and social demands of the 21st century. The campaign has had a huge media and political impact since its release in 2016, and more than 400 public and private schools from the whole Catalan territory have joined it, with the expectation of borrowing and learning from more innovative pedagogies and more flexible forms of school organization. This pro-innovation movement has been received with enthusiasm by key education stakeholders and experts, although there are also those that warn that this initiative could promote further school segmentation (since it is mainly the middle classes who are demanding innovative schools) (Síndic de Greuges, 2016). Nonetheless, for the purpose of this paper, what is more relevant from this campaign is that it challenges de facto the desirability of applying and expanding the influence of external and standardized forms of evaluation. As the 'Escola Nova 21' campaign makes clear, to become advanced and innovative, schools need to be more pedagogically autonomous from public administration prerogatives and adopt forms of comprehensive and personalized evaluation that are not based on standardization. ${ }^{14}$

To sum up, Table 1 gathers the different accountability initiatives that have been enacted in Catalonia in the last years by different governments, whereas Table 2 unpacks and classifies these accountability initiatives according to their main orientation. Table 2 shows how a mix of bureaucratic and managerial forms of evaluation currently coexist in Catalonia. Most of these evaluations rely on the external assessment of students' results although, with the exception of a few recent developments, there are not clear or at least large-scale consequences for those agents giving the account. Overall, a low-stakes model of accountability prevails in the country.

Both Tables 1 and 2 reflect that, in the last decade, there has been a sort of governmental activism concerning the design and implementation of numerous forms of evaluation and accountability initiatives in Catalan education. Nonetheless, despite the increasing presence of different forms of accountability in a school's daily life, it is not clear yet whether the adoption of all these accountability measures responds to a coherent and well-coordinated education reform program.

\section{Madrid: accountability as a key component of market-oriented reforms}

During the last twenty years, the region of Madrid has been governed by the Popular Party (PP). Ideologically speaking, this political party embraces conservative and liberal values at the same time (Puelles Benítez, 2004). Its educational model fits within what Apple calls conservative modernization (Apple, 2006), an education reform agenda comprising 'competition, markets and choice, 
on the one hand, and accountability, performance objectives, standards, national and state testing, and national and state-wide curriculum, on the other' (Apple, 2006: 55). The accountability reform process advanced by the PP in Madrid starts in 2003, the year in which Esperanza Aguirre, regional leader of the party, became the president of the region, a position that she would occupy until 2012.

\section{First reform period (2003-2007): transparency and common core standards}

The education reform carried out in Madrid is highly indebted to President Aguirre's personal preferences on education policy. She declares herself an admirer of political figures such as Margaret Thatcher, as well as a faithful advocate of 'freedom'. ${ }^{15}$ In her 2003 investiture debate, President Aguirre announced the introduction of a standardized test in education, ${ }^{16}$ which would have two main qualities: first, it would allow students, teachers, parents and the educational administration to find out whether students' knowledge match the aims of primary education; and, second, it would infuse the Madrilenian educational system with further transparency, understood as the publication of schools' results. In that same investiture debate, Aguirre added that school choice would be a main educational goal in her term. With these declarations, she was opening a decade of intense educational reforms in which external assessments, accountability and transparency of schools' results would play an essential role.

The education model of the government of Madrid was constructed and publicly portrayed as an alternative to the educational policies promoted by the social-democratic Spanish Socialist Party at the national level. Sources of the regional Education Department considered the social-democratic educational model as undermining educational excellence, meritocracy and competitiveness ${ }^{17}$ due to its 'comprehensive and obscurantist' character, ${ }^{18}$ its 'sectarianism and demagogy', ${ }^{19}$ and its 'egalitarian fundamentalism' ${ }^{20}$ In fact, the educational policies developed by the PP in Madrid explicitly aimed to 'eradicate from the Madrilenian educational system the principles introduced by the socialist laws'. ${ }^{21}$ The government of President Aguirre was very close to the postulates of the Foundation for Social Studies and Analysis (FAES for its acronym in Spanish), a neoliberal think tank chaired by José María Aznar, Spanish President between 1996 and 2004, that is known for advocating market mechanisms as the best way to improve educational quality (Olmedo and Santa Cruz Grau, 2013).

In 2005, the Education Department of Madrid announced the introduction of a standardized and census-based test named Basic Knowledges and Skills (CDI for its acronym in Spanish) to 6th grade primary education students. The test would be run by the Regional Directorate of Academic Planning and implemented by the Inspection Service. The adoption of the CDI test was justified by the mediocre scores of Spanish students in PISA, ${ }^{22}$ and by the poor results reported by the Inspection Service of Madrid in the 2003-2004 academic year (Order 5420-01/2005).

The first CDI test reported very poor results, with about $30 \%$ of the students not achieving minimum standards in Mathematics and Language. As a way to address these bad results, a 'Basic Skills Improvement General Plan' was adopted. This plan included, among other measures, setting learning standards in Spanish and Mathematics as those measured by the CDI test, ${ }^{23}$ the dissemination of teaching materials that fit these standards, and the implementation of teachers' training initiatives to promote basic skills teaching focus (Consejo Escolar de Madrid, 2009). Overall, these different initiatives reflect the results-driven character of the accountability policies being implemented in Madrid at that time.

The CDI test has been implemented on a yearly basis since 2005. It is compulsory for every school, regardless of whether it is public or private, it has no academic consequences for students, and does not include cut-off points (neither for students nor for schools). In 2005, the schools scores were made public through a ranking, but the belligerent reaction of the educational community obliged the Education Department to not rank the school results again, although these results continued being published in a different format. ${ }^{24}$ 
Table 3. Political periods and contemporary educational reform in Madrid.

\begin{tabular}{|c|c|c|c|}
\hline Period & President & Education department & Accountability policies \\
\hline $\begin{array}{l}\text { November } \\
\text { 2003-June } \\
2007\end{array}$ & Esperanza Aguirre & Luis Peral & $\begin{array}{l}\text { 2004: Decree of principals' selection } \\
\text { 2005: fundamental knowledge and skills } \\
\text { standards for Spanish Language and } \\
\text { Mathematics } \\
\text { 2005-2007: 'General Improvement Plan } \\
\text { of Basic Skills' } \\
\text { 2007: School Inspection Organization }\end{array}$ \\
\hline $\begin{array}{l}\text { June } 2007- \\
\text { June } 2015\end{array}$ & $\begin{array}{l}\text { Esperanza Aguirre } \\
\text { Ignacio González }\end{array}$ & Lucía Figar & $\begin{array}{l}\text { 2010: English language proficiency test } \\
\text { 201 I: School Autonomy Decree } \\
\text { 2013: Decree of Free School Choice } \\
\text { 2014: New School Autonomy Decree }\end{array}$ \\
\hline
\end{tabular}

Source: Authors.

\section{Second period (2007-ongoing): school choice, autonomy and competition}

In 2007, Esperanza Aguirre was re-elected as the president of Madrid, and Lucía Figar became the Education Minister of the region (see Table 3). During the investiture debate, president Aguirre insisted on the idea that her government would advocate for transparency in education, as well as for making education stakeholders more responsive to their results. ${ }^{25}$ She also announced that her government would promote two major pro-school choice measures: first, the elimination of the school catchment areas (so parents could choose any Madrilenian school independently of its location); and, second, a program on school autonomy as a way of favoring school diversification and to give more choice options to families. ${ }^{26}$

The announced reforms would mainly materialize in Aguirre's third period in office, which started in 2011. In this period, the freedom of choice principle became even more central in the educational policies and official discourse of the regional government. The Minister of Education of Madrid, Lucía Figar, in different public interventions, endorsed strongly the freedom of school choice idea by following the conventional public choice rationale (i.e., families' choice will trigger competition dynamics between schools, and such competition will generate better quality education at both the school and the system levels).

Families are trapped in their neighbourhoods, and we don't know which schools they want, we don't know if eventually they choose certain schools coerced, because they have not another choice. This will force low demanded schools to put one's skates on. All this improves freedom of choice, equality of opportunities and it also improves quality, because it introduces higher competition among schools and this usually rises the level [of educational quality]. ${ }^{27}$

With Lucía Figar as regional Minister of Education, the two main pro-school choice legislative changes announced by President Aguirre were enacted, namely the Decree on Freedom of School Choice (Decree 29/2013), ${ }^{28}$ and the School Autonomy Decree (Decree 12/2011). ${ }^{29}$ The Decree on Freedom of School Choice's main measure consisted of the removal of the school admission areas, turning the whole region of Madrid into a unique admission area. Another important choicerelated measure included in the decree was the creation of a 'school browser' with general and accessible information about all Madrilenian schools, including the school CDI scores (Villamor and Prieto, 2016). ${ }^{30}$ As a way to promote school choice, the regional Education Department continued making schools' scores public, but with the schools being listed alphabetically and grouped 
by municipalities (unlike in 2005, when the schools were ranked hierarchically by scores). Nonetheless, the school scores were shown in their absolute value and not corrected by the socioeconomic status of students.

The School Autonomy Decree allows schools to modify the schedule, the curriculum, and the methodologies and/or the language of instruction according to their own school educational project. This decree was modified and extended in 2014 (Order 3814/2014) ${ }^{31}$ after the approval of the Spanish reform act LOMCE in 2013 - since LOMCE promotes school autonomy by, among other measures, allowing regional governments and schools to add specific subjects to the ones in the national curriculum, and to decide in which year primary education learning standards should be reached.

However, the type of school autonomy promoted by the Madrilenian educational authorities is, in practice, limited and controlled (cf. Eurydice, 2007). The school autonomy projects require approval from the educational authorities, and they must respond to the fundamental knowledge and skills stated in the curriculum defined by the Education Department. School autonomy, in curricular terms, is restricted because schools are expected to adopt the curricular specialization programs offered by the educational authorities, that is, Spanish-English bilingual education and information and communication technology (ICT) education. Most schools have embraced one of these two programs, with the bilingual program being the most widespread, due to the extra governmental funding that comes with them. The school information browser shows the English language results of the bilingual schools, ${ }^{32}$ as well as which schools have joined any of the curricular specialization programs designed by the Department of Education. For many schools, embracing these specialization programs becomes a sort of marketing strategy because this strengthens their visibility in the browser and because many families see these programs as an education quality hallmark (Prieto and Villamor, 2012).

In Madrid, the official approach to 'school autonomy' is articulated in a way that portrays schools as the main responsible agent for education quality. The principals of low performing schools must identify the causes of underperformance and, accordingly, reinforce organizational issues and/or pedagogic processes through a school improvement plan monitored by the Inspection Service (Dirección General de Innovación, Becas y Ayudas a la Educación, 2016). The schools externally intervened are usually those schools attending the most vulnerable population (Anghel and Cabrales, 2010; Trillo et al., 2006). However, with this type of intervention, low performance is usually associated with school-level aspects, and the economic, cultural and social determinants of school performance tend to be neglected.

In a way, the intensity of the standardized testing dynamic in Madrid has altered the role of traditional education stakeholders. Among other things, it has contributed to narrow down the conventional school support functions of the inspectors. The inspectors now focus on implementing the standardized test, and on supervising the performance improvement plans of low performing schools. ${ }^{33}$ The role of the school principals has also changed drastically within this emerging accountability regime. The government of Madrid conceives school principals as agents of the educational administration whose work and functions need to be professionalized. The Principals' Selection Decree, which was also approved by the Aguirre administration, ${ }^{34}$ states the need to give professional status to school managers through recognizing their responsibility and commitment via economic incentives. The model of principals' selection is highly intervened by the government, and has allowed the Madrilenian educational authorities to choose, on many occasions, their preferred candidates at the expense of the ones proposed by the schools (Bolívar, 2013).

Finally, is worth mentioning that the better scores achieved by the Madrilenian students in the last editions of PISA and the Trends in International Mathematics and Science Study have been portrayed by the educational authorities as clear evidence of the increasing quality and excellence 
of the Madrilenian education system, and of the effectiveness of the educational reforms developed. ${ }^{35}$ The Education Department also highlights that the schools that have endorsed the Bilingual Education Program obtain better results in international assessments than non-bilingual schools. ${ }^{36}$

\section{Responses to accountability in Madrid}

The first application of the CDI test was quite controversial. The Madrilenian Association of Educational Guidance and Psycho-pedagogy ${ }^{37}$ published in 2005 a press release supporting diagnostic assessments but criticizing the CDI test. The Association defended that diagnoses, to be meaningful, should be combined with training and guidance measures. In its opinion, assessments should not only focus on basic skills, and include measures to support low performing students, but also on information related to students' development and students' and schools' sociocultural backgrounds.

These criticisms have been echoed by teachers' unions and parents' associations.Teachers' unions have denounced the lack of scientific rigour of the CDI test and the lack of reliability of the results (pointing out the variability that school scores show yearly), ${ }^{38}$ as well as the political character of the test, arguing that its purpose was simply to promote a market logic in education. ${ }^{39}$ They have called for a boycott against the test several times, and in 2015 called for a sectoral strike on the testing day. ${ }^{40}$

The progressive Federation of Associations of Students' Parents appealed in 2008 against the publication of schools' scores in the Madrilenian Court of Justice, although the appeal did not progress. This has not discouraged the parents' federation from continuing to criticize the test and defending students' and parents' right to opt-out of standardized testing. The federation has spread a justification template for those parents who refuse their children taking the test. ${ }^{41}$ It has also denounced that both teachers and educational authorities put pressure on parents and students to take the exam by threating them about consequences in final grades ${ }^{42}$ or that inspectors go to schools to administer the test without previous notice to prevent students' absence. ${ }^{43}$

In the end of 2013, after ten years of active education reforms, the government of the Community of Madrid had already advanced the main elements of an ambitious educational reform program consisting of the promotion of the external evaluation of schools' performance, school autonomy and freedom of school choice. Table 3 summarizes the different accountability measures that have been developed in Madrid since 2003 to support this education reform agenda, and Table 4 classifies and unpacks these measures by specifying their main characteristics.

The education policies adopted in Madrid apparently promote school autonomy and a more tamed education authorities' intervention. However, behind a pro-freedom and liberal jargon, the Madrilenian educational reform hides a re-regulation process (cf. Ball, 2003) characterized by the promotion of managerial and market forms of accountability in which public authorities play a very active and patronizing role.

\section{Discussion and conclusions}

Kingdon's Agendas, Alternatives and Public Policies (Kingdon, 1984) provides useful analytical categories with which to compare diverging reform trajectories, such as those presented in this paper. According to Kingdon, the key element to understand why a new policy is adopted 'is not where the policy idea comes from, but what made this idea take hold and grow' (Kingdon, 1984: 76). In his theoretical model, the problem, the policy and the political streams are independent elements of the policy process that need to be coupled to provoke effective policy changes. In the two contexts analyzed, Madrid and Catalonia, the accountability reforms are the result of different 


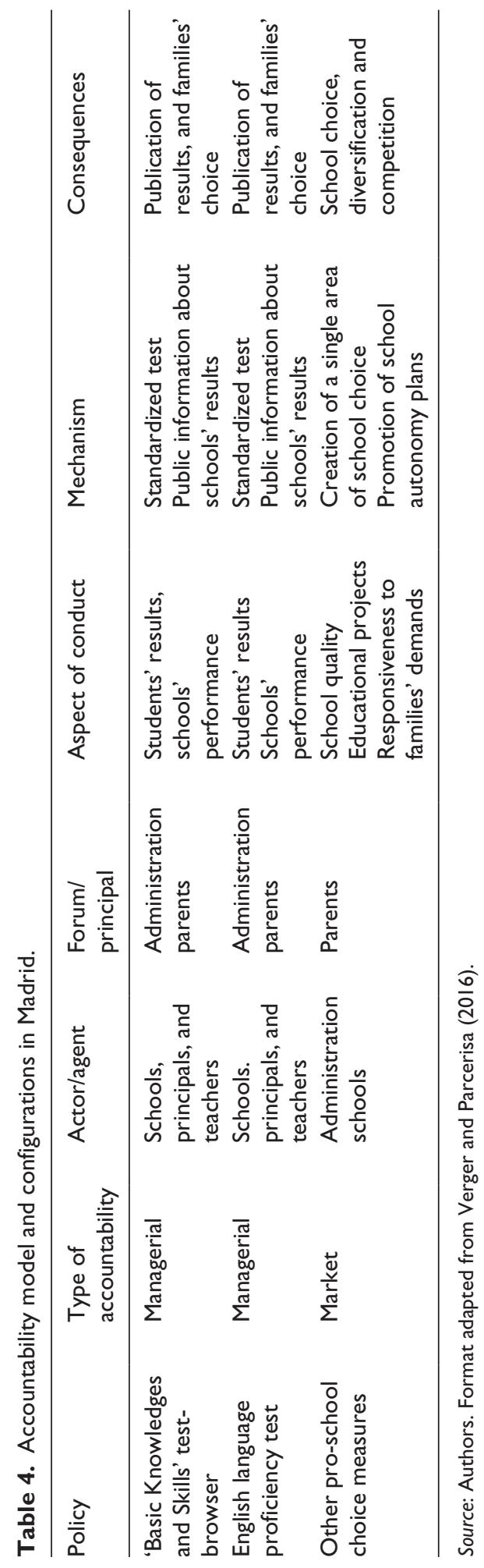


problem-policy-political stream configurations, but also of a different level of coupling between these three elements.

In Madrid, a high level of political continuity of a government that is ideologically committed to market logics in education has contributed to adopt a higher-stakes accountability reform through an incremental policy process. In contrast, in Catalonia, the accountability reforms started with a multiparty left-leaning government. This government introduced new forms of external and internal education evaluation as a way to promote more autonomous and results-based oriented schools; however, the subsequent conservative government interrupted the plans of creating an independent education evaluation agency and meant the strengthening of the evaluation profile of the inspection services instead.

Overall, this paper shows that different political ideologies (namely, social-democrats, conservatives, and neoliberals) seem to converge in the desirability of embracing accountability measures and see external evaluations as a core instrument to address the underperformance of the education system. In a way, education 'excellence' and school 'success' are a common concern in the two analyzed regions. Not surprisingly, mediocre results in PISA in the past have opened a political opportunity window to enact external evaluations of students' and schools' performance. At the same time, when the PISA results have improved, even if they have done so modestly, the regional governments of both Madrid and Catalonia have argued that these improvements are the consequence of their education reforms, including the promotion of school autonomy and the intensification of test-based accountability measures.

However, despite different political forces seeing accountability as a desirable policy approach, they provide accountability with different policy meanings and as a way to advance different education governance models. For instance, the neoliberal government in Madrid sees accountability as a tool to control the transmission of common core standards but, more importantly, to promote school competition and school choice. The social-democratic Catalan government saw accountability as a way to modernize the education system through the promotion of autonomy and an audit culture at the school level (cf. Power, 1997), whereas the conservative government that followed has used accountability measures as a way to control the delivery of common core standards and put more pressure on underperforming schools. The accountability model in Catalonia is predominantly low-stakes and the different Catalan governments - independently of their ideology - have been very reluctant to make the schools' results public so far. Nonetheless, the last conservative government has begun to feel the use of evaluation in a higher stakes way: to pay teachers according to productivity, or to intervene in underperforming schools.

From a multi-scalar education reform perspective, the results of our research are slightly counter-intuitive. We could expect that Catalonia, a region with a strong national identity, would reform education as a way to counter-balance and build scale boundaries with the Spanish regulatory framework. However, the educational reform in Catalonia was initiated in a period of social democratic-led governments in both Catalonia and Spain, and both governments had a similar approach to education and school governance. At that time, the school autonomy with accountability reforms carried out in Catalonia were seen as complementing Spanish education general regulations and, in fact, as a way to interconnect both regulatory scales. ${ }^{44}$ In contrast, the government of Madrid wanted to promote, via market-oriented accountability policies, school choice and school competition as a way to break with the legacy of the comprehensive and pro-equity education model that the social-democratic party had been promoting when governing the country in the 1980s and in the $1990 \mathrm{~s}$.

Together with scale, time is also an important element to understand variegated education reform trajectories. In Madrid, the educational competences were transferred in the year 2000, in a moment of a prominent neo-liberal global hegemony that reinforced the ideological commitment of the regional government to the market education model. In contrast, in Catalonia, the education competences were transferred in the beginning of the 1980s, in a period when Spain was trying to, still far 
Table 5. Multiple streams of accountability reforms.

\begin{tabular}{|c|c|c|c|}
\hline Region & Problem & Policy & Political \\
\hline Madrid & $\begin{array}{l}\text { - Low educational } \\
\text { performance } \\
\text { - Lack of school } \\
\text { competition }\end{array}$ & $\begin{array}{l}\text { - Incremental reform } \\
\text { - High stakes } \\
\text { accountability through } \\
\text { external evaluations } \\
\text { and public information } \\
\text { of school results }\end{array}$ & $\begin{array}{l}\text { Political continuity of a government } \\
\text { ideologically committed to high- } \\
\text { stakes accountability and school } \\
\text { choice } \\
\text { - Regional government reasserts } \\
\text { meritocracy and market principles } \\
\text { in front of the Spanish social- } \\
\text { democratic legacy } \\
\text { - Mediocre Programme for } \\
\text { International Student Assessment } \\
\text { (PISA) results as a window of } \\
\text { political opportunity } \\
\text { - Madrid assumes competences } \\
\text { on education policy in an era of } \\
\text { neoliberal hegemony }\end{array}$ \\
\hline Catalonia & $\begin{array}{l}\text { - Low educational } \\
\text { performance } \\
\text { - Lack of an } \\
\text { evaluation culture. } \\
\text { Excessively } \\
\text { bureaucratic } \\
\text { and centralized } \\
\text { education system }\end{array}$ & $\begin{array}{l}\text { - Uneven reform process } \\
\text { - Low stakes } \\
\text { accountability attached } \\
\text { to the promotion } \\
\text { of school autonomy } \\
\text { (period I) } \\
\text { - Low stakes } \\
\text { accountability as a way } \\
\text { to exercise control } \\
\text { over the curriculum } \\
\text { (period II) }\end{array}$ & $\begin{array}{l}\text { - New autonomy statute allows } \\
\text { the enactment of an autonomic } \\
\text { Education Reform Act } \\
\text { - Mediocre PISA results (together } \\
\text { with other negative socio- } \\
\text { education indicators) as a window } \\
\text { of political opportunity } \\
\text { - Both governments (in periods I } \\
\text { and II) embrace the accountability } \\
\text { norm, but translate it very } \\
\text { differently }\end{array}$ \\
\hline
\end{tabular}

Source: Authors. Based on Kingdon's (1984) categories.

from NPM prerogatives, build a new welfare state. Thus, the school autonomy with accountability reform in Catalonia had to be constructed once a bureaucratic culture of educational governance and evaluation had already sedimented. Thus, together with issues of political discontinuity, path dependent dynamics and the influence of previous policy legacies are behind the uneven nature of the accountability reform trajectory in Catalonia.

In Table 5, on the basis of Kingdon's categories, we summarize what are the main dimensions and elements that conform to the accountability reform processes and their specific re-contextualizations in the two analyzed regions.

The two case studies presented in this paper also allow us to reflect on the complex inter-play between school autonomy and accountability dynamics. Accountability and school autonomy reforms tend to advance simultaneously, since, governments are inclined to strengthen the autonomy status of schools if schools become more open to be regularly evaluated and monitored (see Organization for Economic Co-operation and Development, 2013). This combination of school autonomy with accountability has materialized in the recent educational reforms that Madrid and Catalonia have gone through, but in an uneasy way. Both the concept and the original meaning of school autonomy have been significantly altered and transformed in the two regions. In Catalonia, school autonomy started having a more pedagogic connotation in the early stages of the educational reform but ended up focusing on the managerial dimension of autonomy and on the empowerment and professionalization of the school-principal figure. In a way, the school principal has become the main locus of school autonomy development, according to the official policy framework. 
In Madrid, the government has also conceived school autonomy as a policy for the empowerment and professionalization of principals, but more notably as the pre-condition for school differentiation and competition. However, and paradoxically, the 'school autonomy' program of the government of Madrid has rather promoted more educational homogeneity among schools (Prieto and Villamor, 2012). This program has been conducted in schools adopting centrally-defined bilingual education or ICT programs due to the conditional grants and the positive publicity that the adoption of any of these two programs implies. Overall, this tension between school autonomy and accountability dynamics in education and its implications in terms of educational governance is something that needs further exploration and could be the object of future research.

Finally, our study shows that resistance and criticism to external standardized evaluation and test-based accountability is increasingly coming from educational agents that go beyond teachers' unions. Families, psycho-pedagogic associations and philanthropic organizations are becoming more involved in the politics of education sphere as a consequence of the enactment and intensification of accountability reforms. Many of these actors are concerned with test-based accountability promoting the standardization of learning and undermining innovation in education and advocate alternative forms of accountability and evaluation that are more strongly committed to equity and social justice (see Lingard et al., 2016). Future research could address the nature of new political subjectivities, policy alternatives and forms of collective action that are emerging around the accountability debate and, ultimately, what is their role and influence in education reform processes.

\section{Declaration of Conflicting Interests}

The author(s) declared no potential conflicts of interest with respect to the research, authorship, and/or publication of this article.

\section{Funding}

The author(s) disclosed receipt of the following financial support for the research, authorship, and/or publication of this article: This research has been conducted in the context of the ERC-funded project Reforming Schools Globally: A Multi-Scalar Analysis of Autonomy and Accountability Policies in the Education Sector (REFORMED) (GA-680172).

\section{Notes}

1. Other school evaluations were implemented before, but neither systematically nor with a census range.

2. Available at: http://csda.gencat.cat/web/.content/home/consell_superior_d_avalua/pdf_i_altres/prova_ avaluacio_primaria_2009/avaluacio_primaria.pdf

3. Since 2013 the Global Diagnostic Evaluation has been eliminated in the secondary education.

4. The results of both tests are released every year and target different audiences. Families receive the individual results of their children compared to the results of the Catalan average. Schools receive their results compared with the average results of other schools with a similar students' composition. Finally, an overview of the results at the system level is published in a report that targets policy-makers and practitioners.

5. Available at: http://portaldogc.gencat.cat/utilsEADOP/PDF/6591/1346314.pdf

6. Available at: http://csda.gencat.cat/web/.content/home/consell_superior_d_avalua/pdf_i_altres/prova_ avaluacio_eso_2012/11319055.pdf

7. Departament d'Ensenyament, 2013. Ofensiva de país a favor de l'èxit escolar, p. 22.

8. Available at: http://www.ara.cat/en/Catalonia-Spain-EU-OECD-PISA_0_1701429920.html

9. Avaluació Anual de Centres (AVAC) Subdirecció General de la Inspecció d'Educació, 2015. Available at: http://srvcnpbs.xtec.cat/inslle/docs/20151014_AVAC_Presentacio_Centres_SGIE_2015.pdf

10. See: http://educacio.gencat.cat/documents/IPCNormativa/DOIGC/PEC_Avaluacio_centre.pdf 
11. Available at: http://noalalomce.net/1595-families-desobeeixen-lomce-departament/

12. Available at: https://xarxaescolesinsubmises.wordpress.com/2015/05/18/nota-de-premsa-la-consellera-rigauamenaca-que-expedientara-les-direccions-dels-centres-on-les-families-han-fet-boicot-a-les-proves-wert/

13. Available at: http://www.ara.cat/societat/Rigau-proves-Primaria-contaminacio-politica_0_1353464903. $\mathrm{html}$

14. Available at: http://www.escolanova21.cat/marc-escola-avancada/\#1461157512954-e6ec49a5-dbab

15. See: https://www.youtube.com/watch?v=LdcMLk6MnEk

16. Madrid Assembly Diary of Sessions n ${ }^{\circ}$ 2, VII term, 19 and 20 November 2003, p. 38.

17. See Esperanza Aguirre's declarations in: https:/www.youtube.com/watch?v=Gm90I11XgTU

18. Luis Peral in the Madrid Assembly Diary of Sessions, $n^{\circ}$ 492, VII term, 22 June 2005, p. 14169.

19. See: http://www.fundacionfaes.org/file_upload/publication/pdf/20130520175545en-nombre-de-la-equidad-no-se-puede-extender-la-ignorancia.pdf

20. See Lucía Fígar's declarations in: http://www.madridiario.es/noticia/200964/madrid/criticas-y-apoyosa-la-excelencia-de-aguirre.html

21. See: https://www.youtube.com/watch?v=i2y9RinNb40

22. In $2000,20 \%$ of Spanish students performed at level 1 or below in literacy; in 2003, 23\% of them performed at level 1 or below in mathematics (Organization for Economic Co-operation and Development, 2003, 2004).

23. See: http://www.madrid.org/wleg_pub/secure/normativas/contenidoNormativa.jsf;jsessionid=525FAC6EC8 4AC0558990DF26F47A5306.p0323335?cdestado=P\&nmnorma=3406\&opcion=VerHtml\#no-back-button

24. ElMundoPressnews(2006)availableat:http://www.elmundo.es/elmundo/2006/06/15/madrid/1150367451. html

25. Madrid Assembly Diary of Sessions nº, VIII term, 18 June 2007, p. 36.

26. Madrid Assembly Diary of Sessions n ${ }^{\circ}$, IX term, 14 and 15 June 2011, p. 60.

27. See: http://www.telemadrid.es/?q=programas/elcirculo-primera-hora/lucia-figar-en-el-circulo-1

28. Available at: https://www.bocm.es/boletin/CM_Orden_BOCM/2013/04/12/BOCM-20130412-1.PDF

29. Available at: https://www.bocm.es/boletin/CM_Orden_BOCM/2011/04/15/BOCM-20110415-3.PDF

30. The browser can be found here: http://www.madrid.org/wpad_pub/run/j/MostrarConsultaGeneral.icm

31. Available at: http://www.madrid.org/wleg_pub/secure/normativas/contenidoNormativa.jsf?opcion=Ver Html\&nmnorma $=8798$ \& cdestado $=$ P\#no-back-button

32. See: http://www.bocm.es/boletin/CM_Orden_BOCM/2011/01/21/BOCM-20110121-15.PDF

33. See for instance: https://www.bocm.es/boletin/CM_Orden_BOCM/2016/08/12/BOCM-20160812-9. PDF

34. Available at: http://www.madrid.org/dat_oeste/inspeccion/equipos_directivos/decreto_63_2004.pdf

35. See for instance: http://www.madrid.org/cs/Satellite?blobcol=urldata\&blobheader=application $\% 2 \mathrm{Fpdf \& b}$ lobheadername $1=$ Content-Disposition\&blobheadervalue $1=$ filename $\% 3$ D101203 + CONCLUSIONES + IN FORME+PISA+2009.pdf\&blobkey=id\&blobtable=MungoBlobs\&blobwhere $=1271819634741 \&$ ssbinary $=$ true; https://ppmadrid.es/esperanza-aguirre-resultado-informe-pisa-erradicando-principios-de-leyes-socialistas/

36. See:

http://www.madrid.org/cs/Satellite?blobcol=urldata\&blobheader=application\%2Fpdf\&blobheadername $1=$ Content-Disposition\&blobheadervalue $1=$ filename $\% 3 \mathrm{D} 161220+\mathrm{NP}+\mathrm{CG}+$ Informe + Evaluacion + Bilin guismo +2016 .pdf\&blobkey $=\mathrm{id} \&$ blobtable $=$ MungoBlobs\&blobwhere $=1352920613539 \&$ ssbinary $=$ true

37. This Association represents school counsellors, the professionals in charge of enforcing the tests at schools.

38. See: http://elpais.com/diario/2008/12/16/madrid/1229430259_850215.html

39. Available at: http://www.feccoo-madrid.org/comunes/recursos/15708/doc222503_Posicion_CCOO_ frente_a_las_pruebas_externas_.pdf

40. See: http://www.europapress.es/madrid/noticia-ccoo-madrid-anuncia-huelga-educacion-24-marzo-llama-boicotear-pruebas-cdi-20150226143151.html

41. The template can be found at: http://www.fapaginerdelosrios.org/actualidad/detalles/462/5/

42. Available at: http://www.fapaginerdelosrios.org/actualidad/detalles/462/9/\#detalles 
43. See for instance: http://www.fapaginerdelosrios.org/actualidad/detalles/474/8/\#detalles

44. The educational conflict between the Catalan and the Spanish government would come later on, with the deliberation and approval of the LOMCE. But this conflict did focus on language of instruction issues and the structure of the curriculum, but not on the models of school governance and education evaluation proposed by the Spanish law. See: http://www.elmundo.es/sociedad/2016/06/29/5772db9be2704e0f0e8 b45ac.html

\section{ORCID iDs}

Antoni Verger (iD https://orcid.org/0000-0003-3255-7703

Marcel Pagès (iD) https://orcid.org/0000-0003-3438-9379

\section{References}

Anderson JA (2005) Accountability in Education. Paris, France: UNESCO-International Institute for Educational Planning.

Anghel B and Cabrales A (2010) Los determinantes del éxito en la educación primaria en España [The determinants of success in prmary education in Spain]. Madrid, Spain: FEDEA. [In Spanish.] Available at: http://www.ucl.ac.uk/ uctpcab/research/Primaria.pdf (accessed 10 January 2017).

Apple MW (2006) Educating the 'Right' Way: Markets, Standards, God, and Inequality. New York, NY: Routledge.

Ball SJ (2003) The teacher's soul and the terrors of performativity. Journal of Education Policy 18(2): $215-$ 228.

Ball SJ (2016) Following policy: Networks, network ethnography and education policy mobilities. Journal of Education Policy 31(5); 549-566.

Benito RY and González I (2007) Processos de segregació escolar a Catalunya [Processes of school segregation in Catalonia]. Barcelona, Spain: Fundació Jaume Bofill. [In Spanish.] Available at: http://www. fbofill.cat/sites/default/files/464.pdf (accessed 14 February 2017).

Bolívar A (2013) La dirección escolar en España: de la gestión al liderazgo [School management in Spain: from management to leadership]. In: Villa A (ed.) Liderazgo pedagógico en los centros educativos: Competencias de equipos directivos, profesorado y orientadores [Pedagogical leadership in educational centers: Competencies of management teams, teachers and counselors.] Bilbao, Spain: Universidad de Deusto y Ediciones Mensajero, pp.145-177. [In Spanish.]

Bonal X (2000) Interest groups and the State in contemporary Spanish education policy. Journal of Education Policy 15(2); 201-216.

Bonal X and Verger A (2013) L'agenda de la política educativa a Catalunya: una anàlisi de les opcions de govern (2011-2013) [The agenda of the educational policy to Catalonia: an analysis of the options of government (2011-2013)]. Barcelona, Spain: Fundació Jaume Bofill. [In Spanish.] Available at: http:// www.tercersector.cat/sites/tercersector.cat/files/587.pdf (accessed 22 February 2017).

Bovens M (2007) Analyzing and assessing accountability: A conceptual framework. European Law Journal 13(4); 447-468. Choi A and Jerrim J (2016) The use (and misuse) of PISA in guiding policy reform: The case of Spain. Comparative Education 52(2): 230-245.

Carnoy M (2015) International Test Score Comparisons and Educational Policy: A Review of the Critiques. Boulder, CO: National Education Policy Center. Available at: http://nepc.colorado.edu/publication/ international-test-scores (accesed 6 January 2017).

Collet-Sabé J (2017) 'I do not like what I am becoming but...': Transforming the identity of head teachers in Catalonia. Journal of Education Policy 32(2): 141-158.

Consejo Escolar de Madrid (2009) INFORME 2008: Informe sobre la situación de la Enseñanza no Universitaria en la Comunidad de Madrid. Curso 2006- 2007 [2008 REPORT: Report on the situation of non-university education in the Community of Madrid. Course 2006-2007]. Educación y Participación 18. [In Spanish.] Available at: http://www.comunidad.madrid/publicacion/1142542004543 (accessed 12 June 2018). 
Dale R (2005) Globalisation, knowledge economy and comparative education. Comparative Education 41(2): $117-149$.

Dirección General de Innovación, Becas y Ayudas a la Educación (2016) Pruebas de Conocimientos y Destrezas Indispensables (CDI) en la Comunidad de Madrid (2005-2015) [Indispensable Knowledge and Skills Test (CDI) in the Community of Madrid (2005-2015)]. Madrid, Spain: Consejería de Educación, Juventud y Deporte. [In Spanish.] Available at: http://www.madrid.org/bvirtual/BVCM016299.pdf (acccessed 10 March 2017).

Engel LC (2008) Globalization's strategic union: Decentralization, efficiency, and the implications for educational governance in Spain. In: Hopson RK, Camp Yeakey C and Musa Boakari F (eds) Power, Voice and the Public Good: Schooling and Education in Global Societies. Bingley, UK: Emerald Group Publishing Limited, pp.391-417.

Eurydice (2007) School Autonomy in Europe: Policies and Measures. Brussels, Belgium: Eurydice.

Gallego R, Barbieri N and González S (2017) Explaining cross-regional policy variation in public sector reform: Institutions and change actors in the health sector in Spain. Public Policy and Administration 32(1): 24-44.

Garcia-Alegre E and Del Campo-Canals M (2012) ¿La corresponsabilidad es una estrategia de éxito? [Is coresponsibility a success strategy?] Revista de Educación 359(2): 220-248. [In Spanish.]

Gray G and Jones MD (2016) A qualitative narrative policy framework? Examining the policy narratives of US campaign finance regulatory reform. Public Policy and Administration 31(3): 193-220.

Hamilton LS, Stecher BM and Klein SP (2002) Making Sense of Test-Based Accountability in Education. Santa Monica, CA: Rand Corporation.

Kingdon JW (1984) Agendas, Alternatives, and Public Policies. Boston, MA: Little Brown.

Leithwood K and Earl L (2000) Educational accountability effects: An international perspective. Peabody Journal of Education 75(4): 1-18.

Lingard B, Martino W and Rezai-Rashti G (2013) Testing regimes, accountabilities and education policy: Commensurate global and national developments. Journal of Education Policy 28(5): 539-556.

Lingard B, Martino W, Rezai-Rashti G, et al. (2016) Globalizing Educational Accountabilities. New York, NY: Routledge.

Maragall E (2009) Com governem l'educació [How do we govern education?\}. Minister of Education Conference, Palau de la Generalitat, Barcelona, Spain, 21 October 2009. [In Spanish.] Available at: http://premsa.gencat.cat/pres_fsvp/docs/2009/11/12/09/49/e4a197be-afaa-4379-a33a-c042526ff69f.pdf (accessed 24 March 2017).

Maroy C, Pons X and Dupuy C (2016) Vernacular globalisations: Neo-statist accountability policies in France and Quebec education. Journal of Education Policy 32(1): 100-122.

Mukhopadhyay R and Sriprakash A (2011) Global frameworks, local contingencies: Policy translations and education development in India. Compare 41(3): 311-326.

Olmedo A and Santa Cruz Grau E (2013) Neoliberalism, policy advocacy networks and think tanks in the Spanish educational arena: The case of FAES. Education Inquiry 4(3): 473-496.

Organization for Economic Co-operation and Development (2003) Literacy Skills for the World of Tomorrow. Further results from PISA 2000. Available at: https://www.oecd.org/edu/school/2960581.pdf (accessed 5 January 2017).

Organization for Economic Co-operation and Development (2004) Learning for Tomorrow's World. First results from PISA 2003. Available at: https://www.oecd.org/edu/school/programmeforinternationalstudentassessmentpisa/34002216.pdf (accesed 5 January 2017).

Organization for Economic Co-operation and Development (2013) Synergies for Better Learning: An International Perspective on Evaluation and Assessment. Paris, France: Organization for Economic Co-operation and Development.

Papanastasiou N (2017) How does scale mean? A critical approach to scale in the study of policy. Critical Policy Studies 11(1): 39-56.

Parcerisa L (2016) Modernización conservadora y privatización en la educación: el caso de la LOMCE y la Nueva Gestión Pública [Conservative modernization and privatization in education: the case of the 
LOMCE and the New Public Management]. Revista Educación, Politica y Sociedad 1(2): 11-42. [In Spanish.]

Power M (1997) The Audit Society: Rituals of Verification. Oxford, UK: Oxford University Press.

Prieto M and Villamor P (2012) Libertad de elección, competencia y calidad: las políticas educativas de la Comunidad de Madrid [Freedom of choice, competence and quality: The educational policies of the Community of Madrid]. Profesorado, Revista de Curriculum y Formación del Profesorado 16(3): 127144. [In Spanish.]

Puelles Benítez M (2004) Política y Educación en la España Contemporánea [Politics and Education in Contemporary Spain]. Madrid, Spain: UNED. [In Spanish.]

Ranson S (2003) Public accountability in the age of neoliberal governance. Journal of Education Policy 18(5): 459-480.

Robertson SL (2012) Researching global education policy: Angles in/on/out... Global Education Policy and International Development: New Agendas, Issues, and Policies, pp.33-53. Available at: https:// susanleerobertson.files.wordpress.com/2012/07/2012-robertson-researching-global.pdf (accessed 23 February 2017).

Síndic de Greuges (2016) La segregació escolar a Catalunya (II): condicions d'escolarització [School segregation in Catalonia (II): schooling conditions]. Barcelona, Spain: Síndic de Greuges, Generalitat de Catalunya. [In Spanish.] Available at: http://www.sindic.cat/site/unitFiles/4227/Informe\%20segregacio\%20escolar_II_condicions_escolaritzacio_def.pdf (accessed 16 March 2017).

Schriewer J (2012) Editorial: Meaning constellations in the world society. Comparative Education 48(4): 411-422.

Steiner-Khamsi G and Stolpe I (2006) Educational Import: Local Encounters with Global Forces in Mongolia. New York, NY: Palgrave Macmillan.

Trillo D, Pérez M and Crespo JM (2006) Análisis socioeconómico de lrendimiento en la prueba de conocimientos y destrezas imprescindibles de la Comunidad de Madrid [Socioeconomic analysis of the performance in the test of knowledge and essential skills of the Community of Madrid]. Papeles de Trabajo del Instituto de Estudios Fiscales. Serie Economía 31(1): 3-40. [In Spanish.]

Verger A and Curran M (2016) The dissemination and adoption of NPM ideas in Catalan education: A cultural political economy approach. In: Gunter HM., Grimaldi E, Hall D, et al. (eds) New Public Management and the Reform of Education: European Lessons for Policy and Practice. 1st edition. New York, NY: Routledge, pp.111-124.

Verger A, Fontdevila C and Zancajo A (2016) The Privatization of Education: A Political Economy of Global Education Reform. New York, NY: Teachers College Press.

Verger A and Parcerisa L (2017) Accountability and education in the post-2015 period: International trends, enactment dynamics and socio-educational effects. Think Piece for the UNESCO Global Education Monitoring Report 2017. Available at: http://unesdoc.unesco.org/images/0025/002595/259559e.pdf (accessed).

Villamor P and Prieto M (2016) Reformas hacia la privatización en la Comunidad de Madrid [Reforms towards privatization in the Community of Madrid]. Revista de la Asociación de Sociología de la Educación 9(2): 265-276. [In Spanish.]

\section{Author Biographies}

Antoni Verger is an associate professor at the Department of Sociology of the Universitat Autonoma de Barcelona. His research focuses on the study of the relationship between global governance institutions and the enactment of education policy. Since 2016, he coordinates the ERC-funded project REFORMED Reforming Schools Globally: A Multiscalar Analysis of Autonomy and Accountability Policies in the Education Sector.

Miriam Prieto is Assistant Professor in the Department of Didactics and Educational Theory at the Autonomous University of Madrid. Her research looks at education systems' reform processes and focuses on educational policies and their shaping of pedagogical concepts and practices. 
Marcel Pagès is a PhD student at the Department of Sociology of the Universitat Autònoma de Barcelona. His main research interests include the political sociology of education reform and the relationship between education reform processes and education inequalities.

Patricia Villamor is a professor at the Department of Educational Studies of the Complutense University of Madrid. Her research focuses on teacher training and on the comparative analysis of education systems' reforms, and pays special attention to different forms of educational privatization. 